\title{
E-WASTE QUANTITY AND DISPOSAL AMONG HOUSEHOLDS, SOUTHWESTERN NIGERIA
}

\author{
Babatunde A. AODU*1, Margret O. JEGEDE ${ }^{2}$ and Mathew. O. ILORI ${ }^{2}$ \\ ${ }^{1}$ National Centre for Technology Management (NACETEM), Obafemi Awolowo University, Nigeria. \\ ${ }^{2}$ African Institute for Science Policy and Innovation (AISPI), Obafemi Awolowo University, Nigeria.
}

\begin{abstract}
This study evaluated e-waste management practices among households in Southwestern Nigeria using selected local government areas. It estimated the quantity of specific e-waste category and items generated by the households, and investigated the methods used by the households to dispose e-waste generated. These were with a view to providing reliable and specific e-waste data that would guide decision making on sustainable e-waste management, particularly at local level. The study approach was retrospective and ex-post, thus, covered a five-year period $(2013-2018)$ of household activities within the study area. This research mainly employed a survey method, using a set of questionnaire designed for the study respondents. The questionnaire was administered on 300 households through household representatives/heads, selected through a multi-stage sampling technique. Although, IT/Telecommunication e-waste category (39.9\%) accounted for the largest percentage share of the total households' e-waste generated (in units); large household e-waste category (72.9\%) constituted a principal quantity (in terms of percentage by weight) of the total e-waste generated by the households' $-31,054.50 \mathrm{~kg}$, within the five-year period. The fate of households' ewaste generated were largely informal.
\end{abstract}

Keywords: disposal, e-waste, household, management, practice, Nigeria

\section{INTRODUCTION}

Essentially, e-waste refers to waste emanating from Electrical and Electronic Equipment (EEE). Ewaste denotes all EEE items - unused or reusable, that has been discarded by their first owners (terminology adopted context for this paper). Beyond the various contextual, but convergent definitions (Nnorom et al., 2007; OECD, 2001; STEP, 2014) and categories of ewaste- notably the European Union Classification (see: Van Rossem, 2002; Widmer et al., 2005; Antrekowitsch et al., 2006); some of the challenges of e-waste include the rising quantity (Kiddee et al., 2013; Buekens and Yang, 2014), complex material composition and post consumption attitudinal behavior of EEE consumers -often unwholesome in developing country context. E-waste is ubiquitous and an enormous source of pollution, with environmental and public health implications (Deng et al., 2007; Tseng et al., 2008; Wang et al., 2011; Gao et al., 2011; Huang et al., 2011; Wu et al., 2011; Chen et al. 2011; Ni et al., 2013; Ding et al. 2012; Law and Covaci, 2014; Rao, 2014). However, the waste also has significant economic value (Grant and Oteng-Ababio, 2012), being a very rich source of recyclable and reusable materials including precious metals (Izatt et al., 2012). Consequently, sustainable management of e-waste is imperative at all levels of economy.

The high obsolescence rate of EEE, occasioned by short technological innovation cycle and the general attitude of consumers to dump old equipment for cheap - old or new, but effective and efficient ones, are some of the factors responsible for the consistent rise in the quantity of annual e-waste generated. Globally, an estimated e-waste volume of 41.8 million metric tonnes (Mt) $(5.9 \mathrm{~kg} /$ inhabitants) and 44.7 million Mt (6.1 kg/inhabitant) was generated in 2014 and 2016, respectively (Baldé et al., 2014; Baldé et al., 2017). Respectively figures for 2018 and 2021 were estimated to be around 49.8 million Mt (6.6 $\mathrm{kg} /$ inhabitant $)$ and 52.2 million Mt (6.8 kg/Inhabitant), at an annual growth rate of 4-5\% (Baldé et al., 2017). By this estimates, e-waste is now the fastest growing solid waste stream (Ravi, 2012) in both developed and developing countries. However, predominant e-waste management practices (including primitive treatment and unsafe disposal/collection) among stakeholders in developing countries are potentially dangerous (an indication of environment and public health hazard) and may as well led to suboptimal quality and quantity of recyclable or recoverable substances from the waste. On this premise, mainstream literature 
(including Nnorom and Osibanjo, 2008; Huang et al., 2011; Wu et al., 2011; Chen et al. 2011; Ding et al. 2012; Ni et al., 2013; Law and Covaci, 2014; Rao, 2014) has empirically shown and emphasized the exigent need for a proper management of e-waste, most especially in developing countries.

Although developed countries have the largest annual share of e-waste generated on a global scalefor instance,12.3 million Mt and11.3 million $\mathrm{Mt}$ in Europe and America respectively (Baldéet al., 2017). However, the challenge of the waste in developing countries is even more worrisome. Persistent influx of imported e-waste and primitive treatment/handling of the waste - generally informal, are some of the major challenges confronting sustainable e-waste management in the region. Strong e-waste regulations/enforcements and their resultant economic impact on the part of stakeholders in developed countries, largely contributes to influx/inflow of ewaste into developing countries, particularly Nigeriawith no specific e-waste regulatory framework. At least, $80 \%$ of e-waste generated from the developed countries flows into developing economies (Hicks et al., 2005). In the Nigeria case, about $77 \%$ of e-waste imported into Nigeria originated from Europe (Baldé et al., 2017); out of which 50\% of the total import are in deplorable conditions (Nnorom and Osibanjo, 2008). Furthermore, consumers' desire for updated EEE - in "bridging the digital divide", coupled with socio-economic realities in Nigeria provides a thriving market for imported e-waste - locally termed 'secondhand'. Overtime, the relative volume of ewaste in developing countries will exceed those of developed economies (Yu et al., 2010; Dwivedi and Mittal, 2010).

Nigeria, being the most populous country in Africa also contributes a prime share to the continent's total e-waste volume. Nigeria contributed an estimated volume of 1.1 million $\mathrm{Mt}$ to the total e-waste volume in Africa (Nnorom and Osibanjo, 2008) and still on the increase (Ogundiran et al., 2014). Annually, imported e-waste inflow into Nigeria accounts for about 640,000 Mt (Nnorom and Osibanjo, 2008). However, this estimate may be short of the total imports of ewaste from neighboring countries taking into consideration countless numbers and porosity of Nigeria borders. The current quantities of e-waste are grossly underestimated (Ongondo et.al., 2011; Baldé et al., 2017), most especially in developing countries that place little or no attention to the danger of rising e-waste volume. A country's specific e-waste policy and regulatory framework is a pointer (an indicator) to the country's level of seriousness on e-waste management. Essentially, underestimated e-waste volume/quantity within a defined geographical boundary delimits e-waste management plan and strategies.

Availability and adequacy of basic information on e-waste management practices, particularly in the direction of specific e-waste: types, volume/quantity and disposal method, among stakeholders could be a starting point for sustainable e-waste management in Nigeria. These information has a very strong bearing on designing an effective and efficient e-waste management system (involving collection, sorting, transportation, storage and recycling). Considering the socio-economic situation (high inflation, increasing unemployment and growing poverty level) in Nigeria, growing e-waste could create a lucrative business niche. In fact, eco-innovative management of e-waste in Nigeria largely depends on e-waste inventory data/information among stakeholders within specific geographical - local and/or national.

This paper attempts to study e-waste management practices among households in Southwestern Nigeria. Attempts were made to estimate the quantity of specific e-waste category and items generated by the households and also investigate the destinations of households' e-waste generated within the study area and population.

\section{METHODOLOGY}

\section{A. Study Population}

This study was carried out in Southwestern Nigeria which comprises Lagos, Ogun, Oyo, Osun, Ondo and Ekiti States. The region bears a land mass of 76,852 square kilometers and population of more than 25.2 million people. This geopolitical zone controls more than $50 \%$ of Nigeria's industrial capacity. Southwestern states, particularly Lagos, Ogun and Oyo remain a significant commercial and economic hub of Nigeria. The region has one of the largest and busiest ports (airport and seaport) in Africa, attracting a relatively significant domestic and international trade and migration. Logically, the region is one of the highest generators of any form of waste owing to its peculiar socio-economic and demographic characteristics; hence, a justification for the study area. For the purpose of this study, Lagos and Oyo state were purposively selected due to their relatively larger population sizes and higher estimated number of households.

\section{B. Sample Technique and Size}


Stratified sampling technique was first used to divide the twenty (20) and thirty-three (33) Local Government Areas (LGAs) in Lagos and Oyo State, respectively into already existing senatorial districts. This was followed by purposive sampling of a local government with the highest population of people from each of the senatorial districts in the respective states. A total number of six (6) LGAs comprising three (3) LGAs from each state were used for this study. Then, a random sample of fifty (50) households from each of the selected LGAs; making a total sample size of three hundred (300) households. The six LGAs that were used for this study are Alimosho (Lagos West Senatorial District), Kosofe (Lagos East Senatorial District) and Surulere (Lagos Central Senatorial District) in Lagos State; and Ibadan Central (Oyo South Senatorial District), Egbeda (Oyo Central Senatorial District) and Saki West (Oyo North Senatorial District) in Oyo States.

\section{Research Instruments and Data Collection}

Primary and secondary data were both employed for this study. The primary data were collected with the aid of a structured questionnaire. The questionnaire was administered directly on households through household representative/heads. The questionnaire was structured into three parts: (1) socio-demographic characteristics - respondents and household;(2) aggregated units of e-waste items per category, generated over a five-year period (20132018); and (3) e-waste disposal channels employed by the households. The first part captured sociodemographic data about respondents - age, gender, educational attainment; and household - total monthly income, size, members in and nature of active job. The second part focused on aggregated units of e-waste items per category disposed over a five-year period, 2013-2018. The third part assessed households' predominant e-waste disposal channels.

Secondary data including the average weight $(\mathrm{kg})$ of e-waste item per unit were sourced from literature (Cobbing, 2008; Wang, 2013; Robinson, 2009). Databases of Nigerian Bureau of Statistics (NBS) and National Population Commission (NPC)were valuable sources for the study population and household data.

This study questionnaire design adopts the European Union WEEE categories and sixteen ewaste items considered for this study were classified into four groups: (1) large household appliances (refrigerator, air-conditioner, washing machine and freezer); (2) small household appliances (Iron, kettle, microwave and toaster); (3) IT/telecommunication equipment (Laptops, Mobile phone, CRT monitors and LCD monitors); and (4) consumer equipment (Cathode Ray Tube Television-CRT TV, Flat panelLCD and LED TV, radio, VCR Player).

The household survey for this study was carried out within the last quarter of the year 2018. A total of three hundred (300) instruments were equally distributed among households in the area and population of study. At the end of the survey, a total number of 242questionnaires (representing $80.7 \%$ of the total questionnaire administered) were retrieved, which eventually formed the basis for the outcome of this research.

\section{RESULT AND DISCUSSION}

\section{A. Estimated Quantity of E-waste Generated among Households in the Study Area}

Table 1 contains information on the total estimated quantity (in unit and tons) of e-waste category and items generated among households in the study area between the period under review, 20132015. A total aggregate of 2,739 units of the e-waste items, were generated by the households within the five-year period. E-waste categories of; IT/Telecommunications, small household, consumer and large household respectively constituted $39.9 \%$, $25.3 \%, 17.8 \%$ and $17.0 \%$ of the total units. This is on account of varying obsolescence - technical, feature, economic and aesthetic (Osibanjo and Nnorom, 2007) of EEE categories/items being used among the households. The lifespan of EEE is a significant determinant of obsolescence rate of these products (Balde et al., 2017), thus, varying e-waste quantity. Furthermore, rapid technological innovation (as evidenced in growing/diverse manufacturers and product differentiations), particularly in the case of IT/Telecommunication devices, could also account for the relatively high obsolescence rate of this e-waste category. This is occasioned by the general attitude of consumers to disengage from the use of these appliances and opt for upgraded devices. In fact, technological development coupled with early obsolescence in EEE usage (Ogungbuyi et al., 2012) could exacerbate growing e-waste volume. For instance, studies have shown that the average lifespan of a new IT/Telecommunications appliances including computer, mobile phones and laptops has decreased to less than 3 years (Widmer et al., 2005; Osibanjo and Nnorom 2007; Ogungbuyi et al., 2012; Chi et al., 2014). However, for large household appliances, the average lifespan is comparably longer - washing 
machine (7.1 years), Televisions (8.1 years) and refrigerators (8.6 years) (Chi et al., 2014). Therefore, the relative percentage share and varying quantity (in units) of each category of e-waste generated by the households could be on account of this factor obsolescence rates. It is also important to note that the relatively higher percentage share of IT/Telecommunication e-waste category/item disposed by the households could also be linked to the ease and general attitude of households to drop these items for cheap and/or new but better ones. This is particularly so, in view of the socio-economic relevance and applicability of IT/Telecommunications appliances in today's economic realities. On the basis of this study, IT/Telecommunication and small household e-waste had the highest obsolescence rate among the household, and the least was the Large household e-waste category. Related study on estimation of e-waste items generation had also shown that IT/Telecommunication e-waste item, specifically mobile phones, had the highest obsolescence rate, consequently, constituted the highest volume (in units) (Andarani and Goto, 2013; Chi et al., 2014) of total ewaste estimate. Our study result has also shown that the IT/Telecommunications e-waste category and in particular, mobile phones respectively represent the highest unit volume of e-waste category and Items generated among households in the study area over the five-year period. The proximity of our survey results to those of Andarani and Goto (2013) and Chi et al., 2014, verifies the validity of our findings on the quantity of e-waste generated among households.

On the basis of the e-waste estimates in tons, percentage share (by weight) of the total constituents (31.03 tons), for each e-waste category are: large household $(73 \%)$, consumer e-waste (12\%), small household $(8.2 \%)$ and IT/Telecommunication e-waste $(6.8 \%)$. Studies had also indicated that large household e-waste items (washing machine and refrigerator) and consumer e-waste item constituted a major percentage share (by weight) of total e-waste generated (Andarani and Goto, 2013; Saidan and Tarawneh, 2015). Generally, large household e-waste and consumer ewaste items are relatively weightier - major constituents being steel and iron (Robinson, 2009; Kiddee et al., 2013), consequently, constituting the largest percentage share (by weight) of total e-waste generated among the households.

Table 1: Estimated e-waste generated (aggregate) by Households in the study area (2013 - 2018)

Source: Author's Own Survey, 2018

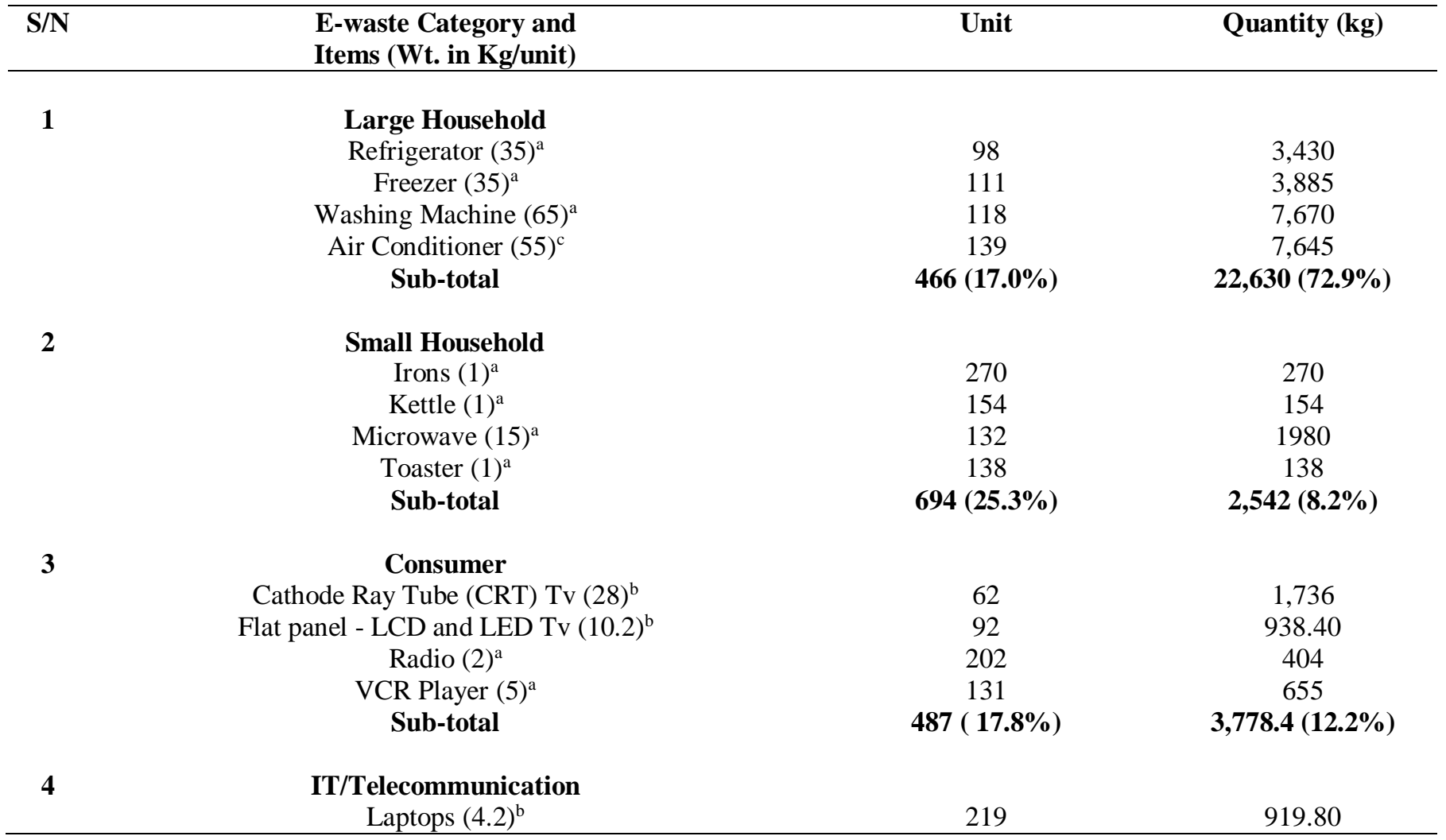


International Journal of Engineering Applied Sciences and Technology, 2020

Vol. 5, Issue 7, ISSN No. 2455-2143, Pages 66-74

Published Online November 2020 in IJEAST (http://www.ijeast.com)

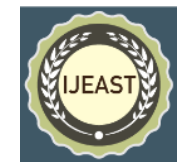

\author{
Mobile phone $(0.1)^{\mathrm{a}}$ \\ CRT monitors (17) ${ }^{\mathrm{b}}$ \\ LCD monitors (5.8) \\ Sub-total
}

$\begin{array}{cc}767 & 76.70 \\ 44 & 748 \\ 62 & 359.60 \\ \mathbf{1 , 0 9 2}(\mathbf{3 9 . 9 \% )} & \mathbf{2 , 1 0 4 . 1 ( 6 . 8 \% )}\end{array}$

$2,739(100 \%)$
Note: ${ }^{\mathrm{a}}$ Cobbing, 2008; ${ }^{\mathrm{b}}$ Wang, 2013; ${ }^{\mathrm{c}}$ Robinson, 2009.

However, Laptop (43.6\%), CRT TV (46.5\%), microwave $(78 \%)$ and washing machine $(33.9 \%)$ constituted the largest percentage share (by weight) of items within each category of e-waste generated by the households, within the five-year period, 2013-2018.

\section{B. Household Choices of E-waste Disposal}

The lack of schemes (such as Extended Producer Responsibility-EPR and Polluters Pay Principles-PPP) in Nigeria (Osibanjo and Nnorom, 2008) has serious implications for end-of-life management of EEE. In developing country context, people are not generally accustomed to such systems, associated with disposal cost or that requires extra responsibility on the part of EEE consumers (Wang et al., 2011). The majority of EEE consumers perceived the product has a tradeable property and as such are used to selling their end-oflife electrical and electronic appliances, thus, thriving second hand markets for the waste - also commonly referred to as used EEE. This is especially the case in Nigeria, as evidenced in growing EEE second hand markets in virtually every major city centers in all States of the Country. Furthermore, established ewaste collection system (formal or informal) at local or national level plays a very vital role in the destination of e-waste emanating from various sources. Formal collection eliminates unsafe and unhygienic e-waste discharges. On the contrary and relatively, the informal means of e-waste collection has gained prominence in developing countries, including Nigeria, attracting actors from the informal sector ( $\mathrm{Yu}$ et al., 2010). The informal collection, mostly done by gipsy peddlers (scrap dealers) reclaims e-waste from households with or without other recyclable waste (including papers, tin cans and glass bottles). Eventually, the collections, particularly the economically valuable ones get separated prior selling to higher level dealer(s) in the value chain. There are a number of post EEE consumption mechanism being employed by EEE consumers in developing countries, however, this study has investigated eight disposal options with a view to examine the mainstream flow of e-waste emanating from households at local levels. The options considered for this study are: (1) Disposed with household waste (A); (2) Sold to second hand market (B); (3) Given/Sold to scrap dealers (C); (4) Hand over to e-waste collectors (D); (5) Sold to Individuals (E); (6) Donation $(F)$ and (7) Store at home $(G)$.

The breakdown and summary of the household ewaste disposal options is has shown in Table 2 below. Discussion in this section is based on the percentage of household for each of the disposal method. The results indicate that on the average, $83 \%, 50 \%, 44 \%$ and $42 \%$ of the total (valid) household respondents (242) disposed of their respective mobile phones, iron, washing machine and radio through different channels. These accounted for the highest household count per e-waste item generated in the study area. Generally, the predominant household choice of disposing e-waste generated in the study area, during this study period was through selling to second hand market. Majority of consumers would prefer to sell their obsolete electrical and electronic appliances to second hand market (Saidan and Tarawneh, 2015). Based on this study, a significant quantity of the ewaste generated among the households ends in second hand market ('B'), chiefly, e-waste items of; large household, consumer and IT/Telecommunications category. On the average, one-third of the 'total HH' disposed large household e-waste items via this channel $-33 \%, 37.4 \%, 40.2 \%$ and $43 \%$ of the total households for refrigerator, freezer, washing machine and air conditioner, respectively. Likewise, $45 \%, 52 \%$, $37.9 \%$ and $27.8 \%$ of the total households (percentage of 'total HH') disposed their LCD/LED Tv, laptops, mobile phones and flat panel monitors to second hand markets.

Relatively, a substantial percentage (more than $20 \%$ ) of the total household counts disposed their large household e-waste items by selling to individuals ('E'). This is also a common e-waste disposal strategy among households (Chi et al., 2014). In this case, this study revealed that e-waste items of VCR player, laptop, mobile phone and LCD/LED $\mathrm{Tv}$ were respectively sold to individuals by $20.5 \%, 26 \%, 35.5 \%$ and $17.5 \%$ of the total households sampled.

A reasonable quantity of the e-waste items also ends in the hand of scrap dealers - informal (e-) waste 
collectors. About 24.8\%, 34\% and $23 \%$ of the total households give/sold their iron, toaster and CRT monitor, respectively to informal waste collectors. The nature of transaction between the households and informal (e-)waste collector is beyond the scope of this study. This study is in particular interested in the outcome (in this case, final e-waste destination) and not process. Thus, the option of household to give/sold e-waste item to scrap dealers (' $C$ ') was not differentiated. A number of households also disposed their e-waste generated with household waste ('A') - majorly iron $(24 \%)$, kettle $(26 \%)$, radio $(15.5 \%)$ and flat panel monitor $(19.7 \%) .21 .7 \%$ of the households store/keep CRT Tv at home, representing the highest household percentage for the disposal method. Generally, the percentage of households that handed their e-waste to formal e-waste collectors ('D') were relatively low for all the e-waste items. Chi et al., 2014 had also reported an insignificant household e-waste collection through formal sector in a developing country context.

\section{E-waste Disposal Methods}

Household percentage (\%) and Count $(\mathrm{N})$

\begin{tabular}{|c|c|c|c|c|c|c|c|c|c|}
\hline $\mathbf{S} / \mathbf{N}$ & E-waste Items & $\mathbf{A}$ & $\mathbf{B}$ & $\mathbf{C}$ & D & $\mathbf{E}$ & $\mathbf{F}$ & $\mathbf{G}$ & Total HH \\
\hline 1 & Refrigerator & $\begin{array}{l}8.5 \% \\
(8)\end{array}$ & $\begin{array}{l}33 \% \\
(31)\end{array}$ & $\begin{array}{c}14.9 \% \\
(14)\end{array}$ & $\begin{array}{c}6.4 \% \\
(6)\end{array}$ & $\begin{array}{c}20.2 \% \\
(19)\end{array}$ & $\begin{array}{l}5.3 \% \\
(5)\end{array}$ & $\begin{array}{c}11.7 \% \\
(11)\end{array}$ & 94 \\
\hline 2 & Freezer & $\begin{array}{c}6.1 \% \\
(6)\end{array}$ & $\begin{array}{c}37.4 \% \\
(37)\end{array}$ & $\begin{array}{c}12.1 \% \\
(12)\end{array}$ & $\begin{array}{c}3.0 \% \\
(3)\end{array}$ & $\begin{array}{c}22.2 \% \\
(22)\end{array}$ & $\begin{array}{c}11.1 \% \\
(11)\end{array}$ & $\begin{array}{c}8.1 \% \\
(8)\end{array}$ & 99 \\
\hline 3 & Washing Machine & $\begin{array}{c}2.8 \% \\
(3)\end{array}$ & $\begin{array}{c}40.2 \% \\
(43)\end{array}$ & $\begin{array}{l}15 \% \\
(16)\end{array}$ & $\begin{array}{c}2.8 \% \\
(3)\end{array}$ & $\begin{array}{c}25.2 \% \\
(27)\end{array}$ & $\begin{array}{c}3.7 \% \\
(4)\end{array}$ & $\begin{array}{c}10.3 \% \\
(11)\end{array}$ & 107 \\
\hline 4 & Air Conditioner & $\begin{array}{c}5.9 \% \\
(6)\end{array}$ & $\begin{array}{r}43 \% \\
(44)\end{array}$ & $\begin{array}{c}8.8 \% \\
(9)\end{array}$ & $\begin{array}{l}1 \% \\
(1)\end{array}$ & $\begin{array}{c}22.6 \% \\
(23)\end{array}$ & $\begin{array}{c}6.9 \% \\
(7)\end{array}$ & $\begin{array}{c}11.8 \% \\
(12)\end{array}$ & 102 \\
\hline 5 & Iron & $\begin{array}{l}24 \% \\
(29)\end{array}$ & $\begin{array}{c}18.2 \% \\
(22)\end{array}$ & $\begin{array}{c}24.8 \% \\
(30)\end{array}$ & $\begin{array}{c}6.6 \% \\
(8)\end{array}$ & $\begin{array}{c}9.9 \% \\
(12)\end{array}$ & $\begin{array}{c}5.8 \% \\
(7)\end{array}$ & $\begin{array}{c}10.7 \% \\
(13)\end{array}$ & 121 \\
\hline 6 & Kettle & $\begin{array}{c}26.0 \% \\
(25)\end{array}$ & $\begin{array}{l}23 \% \\
(22)\end{array}$ & $\begin{array}{c}15.6 \% \\
(15)\end{array}$ & $\begin{array}{c}8.3 \% \\
(8)\end{array}$ & $\begin{array}{c}14.6 \% \\
(14)\end{array}$ & $\begin{array}{c}3.1 \% \\
(3)\end{array}$ & $\begin{array}{c}9.4 \% \\
(9)\end{array}$ & 96 \\
\hline 7 & Microwave & $\begin{array}{c}18.3 \% \\
(19)\end{array}$ & $\begin{array}{c}24.0 \% \\
(25)\end{array}$ & $\begin{array}{c}20.2 \% \\
(21)\end{array}$ & $\begin{array}{c}3.8 \% \\
(4)\end{array}$ & $\begin{array}{c}15.4 \% \\
(16)\end{array}$ & $\begin{array}{c}8.7 \% \\
(9)\end{array}$ & $\begin{array}{c}9.6 \% \\
(10)\end{array}$ & 104 \\
\hline 8 & Toaster & $\begin{array}{c}13.8 \% \\
(13)\end{array}$ & $\begin{array}{c}21.3 \% \\
(20)\end{array}$ & $\begin{array}{c}34.0 \% \\
(32)\end{array}$ & $\begin{array}{c}6.4 \% \\
(6)\end{array}$ & $\begin{array}{c}11.7 \% \\
(11)\end{array}$ & $\begin{array}{c}4.3 \% \\
\text { (4) }\end{array}$ & $\begin{array}{c}8.5 \% \\
(8)\end{array}$ & 94 \\
\hline 9 & CRT TV & $\begin{array}{c}5.8 \% \\
(4)\end{array}$ & $\begin{array}{c}26.1 \% \\
(18)\end{array}$ & $\begin{array}{c}21.7 \% \\
(15)\end{array}$ & $\begin{array}{c}8.7 \% \\
(6)\end{array}$ & $\begin{array}{c}8.7 \% \\
(6)\end{array}$ & $\begin{array}{c}7.3 \% \\
(5)\end{array}$ & $\begin{array}{c}21.7 \% \\
(15)\end{array}$ & 69 \\
\hline 10 & Flat panel - LCD and LED TV & $\begin{array}{l}5 \% \\
(4)\end{array}$ & $\begin{array}{c}45 \% \\
(36)\end{array}$ & $\begin{array}{c}8.8 \% \\
(7)\end{array}$ & $\begin{array}{l}5 \% \\
(4)\end{array}$ & $\begin{array}{c}17.5 \% \\
(14)\end{array}$ & $\begin{array}{c}11.2 \% \\
(9)\end{array}$ & $\begin{array}{c}7.5 \% \\
(6)\end{array}$ & 80 \\
\hline 11 & Radio & $\begin{array}{c}15.5 \% \\
(16)\end{array}$ & $\begin{array}{c}29.1 \% \\
(30)\end{array}$ & $\begin{array}{c}22.3 \% \\
(23)\end{array}$ & $\begin{array}{c}6.8 \% \\
(7)\end{array}$ & $\begin{array}{c}10.7 \% \\
(11)\end{array}$ & $\begin{array}{c}3.9 \% \\
(4)\end{array}$ & $\begin{array}{c}11.7 \% \\
(12)\end{array}$ & 103 \\
\hline 12 & VCR Player & $\begin{array}{c}10.8 \% \\
(9)\end{array}$ & $\begin{array}{c}24.1 \% \\
(20)\end{array}$ & $\begin{array}{c}14.5 \% \\
(12)\end{array}$ & $\begin{array}{c}6.0 \% \\
(5)\end{array}$ & $\begin{array}{c}20.5 \% \\
(17)\end{array}$ & $\begin{array}{c}8.4 \% \\
(7)\end{array}$ & $\begin{array}{c}15.7 \% \\
(13)\end{array}$ & 83 \\
\hline 13 & Laptop & $\begin{array}{c}3.9 \% \\
(5)\end{array}$ & $\begin{array}{l}52 \% \\
(66)\end{array}$ & $\begin{array}{c}8.7 \% \\
(11)\end{array}$ & $\begin{array}{c}2.4 \% \\
(3)\end{array}$ & $\begin{array}{l}26 \% \\
(33)\end{array}$ & $\begin{array}{c}3.1 \% \\
(4)\end{array}$ & $\begin{array}{c}3.9 \% \\
(5)\end{array}$ & 127 \\
\hline 14 & Mobile phone & $\begin{array}{c}7.4 \% \\
(15)\end{array}$ & $\begin{array}{c}37.9 \% \\
(77)\end{array}$ & $\begin{array}{c}5.9 \% \\
(12)\end{array}$ & $\begin{array}{c}1.5 \% \\
(3)\end{array}$ & $\begin{array}{c}35.5 \% \\
(72)\end{array}$ & $\begin{array}{c}7.4 \% \\
(15)\end{array}$ & $\begin{array}{c}4.4 \% \\
(9)\end{array}$ & 203 \\
\hline 15 & CRT Monitor & $\begin{array}{c}12.8 \% \\
(5)\end{array}$ & $\begin{array}{c}17.9 \% \\
(7)\end{array}$ & $\begin{array}{c}23 \% \\
(9)\end{array}$ & $\begin{array}{c}10.3 \% \\
(4)\end{array}$ & $\begin{array}{c}15.4 \% \\
(6)\end{array}$ & $\begin{array}{c}10.3 \% \\
(4)\end{array}$ & $\begin{array}{c}10.3 \% \\
(4)\end{array}$ & 39 \\
\hline 16 & Flat panel Monitor & $\begin{array}{c}19.7 \% \\
(12)\end{array}$ & $\begin{array}{c}27.8 \% \\
(17)\end{array}$ & $\begin{array}{c}18.0 \% \\
(11)\end{array}$ & $\begin{array}{c}6.6 \% \\
(4)\end{array}$ & $\begin{array}{c}14.7 \% \\
(9)\end{array}$ & $\begin{array}{c}6.6 \% \\
(4)\end{array}$ & $\begin{array}{c}6.6 \% \\
(4)\end{array}$ & 61 \\
\hline
\end{tabular}

Table 2: Households' e-waste disposal methods

Source: Author's Own Survey, 2018

Note: A (Disposed with household waste); B (Sold to second hand market); C (Given/Sold to scrap dealers); D (Hand over to e-waste collectors); E (Sold to Individuals); F (Donation) and G (Store at home). 
International Journal of Engineering Applied Sciences and Technology, 2020

Vol. 5, Issue 7, ISSN No. 2455-2143, Pages 66-74

Published Online November 2020 in IJEAST (http://www.ijeast.com)

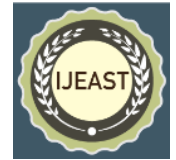

\section{CONCLUSIONS}

Generally, predominant destinations of e-waste generated among households in the study area were secondhand market and individuals. This suggest a large flow of e-waste reuse, which has positive implications for a circular e-waste economy reducing the volume of household e-waste that ends in informal destinations. Based on the questionnaire survey of this study, a total of 2,739 units of e-waste was generated within the five-year period of 20132018. Relatively, the quantity of IT/Telecommunication e-waste accounted for more than $39 \%$ of the total, thus, recycling facilities should prioritize and support an appropriate IT/Telecommunication recycling process. However, the optimal performance of such facility and process (for any of the e-waste category) largely depends on a thorough understanding of consumer behavior, particularly as it concerns factors influencing their choices of e-waste destination - which is beyond the scope of this paper. In terms of percentage by weight (\% by wt.) of total household e-waste generated, the large household and consumer e-waste had the largest share $-72.9 \%$ and $12.2 \%$, respectively. This has implications for e-waste collection, transportation and storage facility. In the context of this study area and time scope, the fate of the e-wastes generated by the households were mostly informal.

\section{REFERENCES}

1. Antrekowitsch, H., Potesser, M., Spruzina, W., and Prior, F. (2006). Metallurgical recycling of electronic scrap. Proceedings of the EPD Congress 2006, (pp. 899-908).

2. Baldé, C. P., Forti V., Gray, V., Kuehr, R., and Stegmann, P. (2017). The Global Ewaste Monitor -United Nations University (UNU), International Telecommunication Union (ITU) \& International Solid Waste Association (ISWA), Bonn/Geneva/Vienna. ISBN Electronic Version: 978-92-808-90549. ISSN 2522- 7033.

3. Baldé, C. P., Wang, F., Kuehr, R., and Huisman, J. (2015). The Global E-waste Monitor - 2014, United Nations University, IAS - SCYCLE, Bonn, Germany. ISBN Electronic Version: 978-92-808-4556-3.

4. Buekens, A., and Yang, J. (2014). Recycling of WEEE plastics. A review. Journal of
Material Cycles and Waste Management. 16, (pp. 415-434).

5. Chen, S. J., Tian, M., Wang, J., Shi, T., Luo, Y., Luo, X. J., and Mai, B. X. (2011). Dechlorane Plus (DP) in air and plants at an electronic waste (e-waste) site in South China. Environmental Pollution. 159, (pp. 1290-1296).

6. Cobbing M. Toxic Tech (2008). Not in Our Backyard. Uncovering the Hidden Flows of e-waste.

Report from Greenpeace International. http://www.greenpeace.org/raw/content/ belgium/fr/press/reports/toxic-tech.pdf, Amsterdam, 2008, (pp. 1-76).

7. Deng, W. J., Zheng, J. S., Bi, X. H., Fu, J. M., and Wong, M. H. (2007). Distribution of PBDEs in air particles from an electronic waste recycling site compared with Guangzhou and Hong Kong, South China. Environment International. 33, (pp. 10631069).

8. Ding, L., Li, Y., et al. (2012). Seasonal trend of ambient PCDD/Fs in Tianjin City, northern China using active sampling strategy. Journal of Environmental Sciences. 24 (11), (pp. 1966-1971).

9. Feng Wang, JacoHuisman, Ab Stevels and Cornelis Peter Balde. (2013). Enhancing ewaste estimates: improving data quality by multivariate input-output analysis. Waste management. 33, (pp. 2397-2407).

10. Gao, S., Wang, J., Yu, Z., Guo, Q., Sheng, G., and Fu, J. (2011). Hexabromocyclododecanes in surface soils from e-waste recycling areas and industrial areas in south China: Concentrations, diastereoisomer- and enantiomer-specific profiles, and inventory. Environmental Science and Technology. 45, (pp. 20932099).

11. Grant, R., and Oteng-Ababio, M. (2012). Mapping the invisible and real "African" economy: Urban e-waste circuitry. Urban Geography. 33 (1), (pp. 1-21).

12. Huang, H., Zhang, S., and Christie, P. (2011). Plant uptake and dissipation of PBDEs in the 
soils of electronic waste recycling sites. Environmental Pollution. 159, (pp. 238243).

13. Kiddee, P., Naidu, R., and Wong, M. H. (2013). Electronic waste management approaches: An overview. Waste Management. 33 (5), (pp. 1237-1250).

14. Law, R. J., Covaci, A., Harrad, S., Herzke, D., Abdallah, M. A. E., Fernie, K., Toms, L. M. L., and Takigami, H. (2014). Levels and trends of PBDEs and HBCDs in the global environment: Status at the end of 2012. Environment International. 65, (pp. 47-158).

15. Maheshwar Dwivedy and R. K. Mittal (2010). Estimation of future outflows of ewaste in India. Waste management. 30, (pp. 483-491).

16. Motasem Saidan, Adnan Tarawneh (2015). Estimation of Potential E-waste Generation in Jordan. Ekoloji. 24, (pp. 60-66). Doi: 10.5053/ekoloji.2015.25.

17. N. E. Izatt, S. R. Izatt and R. L. Bruening (2012). "Green procedure for the selective recovery of precious, specialty, and toxic metals from electronic wastes," 2012 Electronics Goes Green 2012+. Institute of Electrical and Electronics Engineers (IEEE) conference on, (pp. 1-6).

18. Ni, W., Huang, Y., Wang, X., Zhang, J., and $\mathrm{Wu}, \mathrm{K}$. (2013). Associations of neonatal lead, cadmium, chromium and nickel co-exposure with DNA oxidative damage in an electronic waste recycling town. Science of the Total Environment. 472, (pp. 354-362).

19. Nnorom, I. C., and Osibanjo, O. (2008). Overview of electronic waste (e-waste) management practices and legislations and their poor applications in the developing countries. Resources Conservation and Recycling. 52, (pp. 843-858).

20. Nnorom, I. C., Osibanjo, O., and Nnorom, S. O. (2007). Achieving resource conservation in electronic waste management: A review of options available to developing countries. Journal of Applied Sciences. 7, (pp. 29182933).
21. Ogundiran, M. B., Oyetade, O. A., Babayemi, J. O., and Osibanjo, O. (2014). Potential environmental hazards of nonrechargeable electric torch wastes in Nigeria. International Journal of Environment and Waste Management. 13 (2), (pp. 115-130).

22. Olakitan Ogungbuyi, Innocent Chidi Nnorom, Oladele Osibanjo, Mathias Schluep (2012). E-waste country assessment Nigeria. E-waste Africa Project of the Secretariat of the Basel Convention. (pp. 1-94).

23. Organization for Economic Cooperation and Development. (2001). Extended producer responsibility. A guidance manual for governments. Retrieved from http://www.oecd.org/env/environmentalpoli cytoolsand evaluation/extendedproducerresponsibility.h $\underline{\operatorname{tm}}$

24. Pertiwi Andarani, Naohiro Goto (2013). Potential e-waste generated from households in Indonesia using material flow analysis. $\mathbf{J}$ Mater Cycles Waste Manag. DOI 10.1007/s10163-013-0191-0.

25. Rao, L. N. (2014). Environmental impact of uncontrolled disposal of e-wastes. International Journal of Chemical Technology Research. 6 (2), (pp. 13431353).

26. Ravi, V. (2012). Evaluating overall quality of recycling of e-waste from end-of-life computers. Journal of Cleaner Production. 20, (pp. 145-151).

27. Robinson, B.H., 2009. E-waste. An assessment of global production and environmental impacts. Science of the Total Environment. 408, (pp. 183-191).

28. StEP. (2005). Solving the e-waste problem: a synthetic approach (StEP). Draft Project Document. Retrieved from http://www.stepinitiative.org/index. php/InitiativeWhatlsEwaste.html

29. Tseng, L. H., Li, M. H., Tsai, S. S., Lee, C. W., Pan, M. H., Yao, W. J., and Hsu, P. C. (2008). Developmental exposure to decabromodiphenyl ether (PBDE 209): Effects on thyroid hormone and hepatic 


\section{International Journal of Engineering Applied Sciences and Technology, 2020 Vol. 5, Issue 7, ISSN No. 2455-2143, Pages 66-74 \\ Published Online November 2020 in IJEAST (http://www.ijeast.com)}

enzyme activity in male mouse offspring. Chemosphere. 70, (pp. 640-647).

30. Van Rossem, C. (2002) Environmental Product Information Flow Communication of Environmental Data to Facilitate Improvements in the ICT Sector. March 2002. Report No 3102. The International Institute for Industrial and Environmental Economics (IIIEE). Lund University and Swedish National Chemical Inspectorate (KEMI).

31. Wang, H., Han, M., Yang, S., Chen, Y., Liu, Q., and Ke, S. (2011). Urinary heavy metal levels and relevant factors among people exposed to e-waste dismantling. Environment International. 37, (pp. 80-85).

32. Wang, Z.H., Zhang, B., Yin, J.H., Zhang, X., 2011. Willingness and behavior towards ewaste recycling for residents in Beijing city, China. J. Clean. Prod. 19 (9), (pp. 977-984).

33. Widmer R., Oswald-Krapf H., SinhaKhetriwal D., Schnellmann M., and Böni H. (2005): Global Perspectives on e-waste. Environmental Impact Assessment Review. 25, (pp. 436- 458).

34. Wu, J. P., Guan, Y. T., Zhang, Y., Luo, X. J., Zhang, X. H., and Mai, B. X. (2011a). Bioaccumulation potentials of polychlorinated biphenyls in bottom fishes from an e-waste recycling site in South China. Environmental Science. 31, (pp. 637641).

35. Xinwen Chi, Mark Y.L. Wang, Markus A. Reuter (2014). E-waste collection channels and household recycling behaviors in Taizhou of China. Journal of Cleaner Production. 80, (pp. 87-95).

36. Yu, J., Williams, E., Ju, M., and Shao, C. (2010). Managing e-waste in China: Policies, pilot projects and alternative approaches. Resources, Conservation and Recycling. 54, (pp. 991-999). 